\title{
Factors Determining Desirability of Entrepreneurship in Romania
}

\author{
Carmen Păunescu ${ }^{1, *}$, Mihaela Cornelia Popescu ${ }^{2}$ and Matthias Duennweber ${ }^{2}$ \\ 1 UNESCO Department for Business Administration, The Bucharest University of Economic Studies, \\ Romană Square 6, Bucharest 010374, Romania \\ 2 Doctoral School for Business Administration, The Bucharest University of Economic Studies, \\ Romană Square 6, Bucharest 010374, Romania; mihaela_murarita@yahoo.com (M.C.P.); \\ mduennweber@googlemail.com (M.D.) \\ * Correspondence: carmen.paunescu@ase.ro; Tel.: +40-747-776-700
}

Received: 6 September 2018; Accepted: 24 October 2018; Published: 26 October 2018

\begin{abstract}
Studies in entrepreneurship have identified that a positive entrepreneurial attitude and willingness to start a business influence future entrepreneurial intention. In the study of entrepreneurial intention, there is a growing interest in understanding the factors that determine desirability of entrepreneurship. Earlier studies have identified that there is a significant correlation between individuals' perceived desirability of entrepreneurship and their entrepreneurial intention. This study addressed the question of what factors determine the desirability of entrepreneurship and how these different factors affect the desire to become an entrepreneur. We discussed the key determinants of the desirability of entrepreneurship in Romania. Using the Amway Global Entrepreneurship Report (AGER) dataset for 2016, we examined the desirability of entrepreneurship among Romanian respondents by considering multiple factors indicated by the theory as being significant predictors of entrepreneurship: feasibility, social stability, and comfort with acquiring customers, as well as socio-demographic factors such as age, gender, education, income level and working status. The results of our regression analysis demonstrate that social stability and feasibility have the most impact on the desirability of entrepreneurship. In addition, we document that comfort with acquiring customers is perceived as an important factor in increasing the desirability of entrepreneurship. These results suggest that a good understanding of individuals' social environment and their need for skills and capabilities may lead to greater entrepreneurial efficacy, which is fundamental to sustaining economic growth. Future research should be grounded on testing if level of education, working status and income influence desirability of entrepreneurship as our existing data did not prove that it did.
\end{abstract}

Keywords: desirability of entrepreneurship; entrepreneurial intention; entrepreneurship attitude; feasibility of entrepreneurship; social stability; comfort with acquiring customers; Romania

\section{Introduction}

Entrepreneurial activity is the driving engine of a nation's sustainable development and economic progress. Poverty, unequal distribution of wealth, unfair access to the education system and healthcare, unemployment, and a low level of social protection are strong reasons for developing creative ideas into sustainable, successful businesses [1]. Many countries, especially ones with emergent economies, are currently preoccupied with decreasing their unemployment rates and creating more jobs, and entrepreneurship is one of the most desirable ways of reaching this objective [2]. However, earlier studies on entrepreneurship and global reports show that there is a decreasing interest in entrepreneurship and self-employment in many developing countries $[1,3,4]$. 
Different studies regard entrepreneurship as a solution to solving global problems and a driver for economic development and advancement. Entrepreneurship is defined as an intentional behavior to develop a business idea, create new products and services and obtain and generate economic and social benefits $[4,5]$. When it comes to entrepreneurship decisions, people make rational assessments of the different probabilities associated with certain outcomes and alternatives. Following this idea, individuals tend to select those alternatives with the highest probability of a maximized long term benefit and lowest degree of risk [6].

The extant literature in the field of entrepreneurial path development emphasizes the difference between perceived desirability of entrepreneurship, desire for starting a new venture, and entrepreneurial intention as distinct and inter-related concepts. Literature defines entrepreneurial intention as a state of mind that people wish to create a new venture $[5,7]$. When analyzing entrepreneurial intention, scholars consider three major factors: individual-level factors (personal motivation, attitude, risk taking, need for achievement, social relations, and so forth) $[7,8]$, institutional-level factors (regulatory quality, political stability, control of corruption, and so forth) [9] and country-level factors (economic, social protection, etc.) [10]. Other authors stress the importance of entrepreneurial education in expressing entrepreneurial intention [11]. There is broad consensus in the literature on the positive relationship between entrepreneurial intention, on the one hand, and different influencing factors, on the other hand.

Peng et al. (2012) used the terms "entrepreneurial intention" and "entrepreneurial desire" interchangeably [12]. They referred to entrepreneurial intention as "a mental orientation such as desire, wish and hope influencing their choice of entrepreneurship" [12] (p. 96). They explored the influence of three major factors on entrepreneurial intentions: individual/psychological factors (personality traits, entrepreneurial attitude, subjective norms, entrepreneurial self-efficacy, entrepreneurial competence, and prior entrepreneurship experience), family background factors (family entrepreneurship experiences) and social environment factors (entrepreneurial policy support, entrepreneurial environment, and entrepreneurial resistance). Their research proves that entrepreneurial attitude together with entrepreneurial self-efficacy exert a significantly positive influence on entrepreneurial intentions.

Prevailing models of entrepreneurial intentions appear to disregard the difference between desirability of entrepreneurship and entrepreneurial desire, and omit the desire-intentions relationship altogether [13]. The desire to be an entrepreneur can be expressed as possibility seeking. The desirability of entrepreneurship reflects the degree of personal attraction to creating a business. Existing studies have not distinguished desirability as an attitude from desire as a motivation $[5,14,15]$. For example, Krueger et al. (2000) used reflective measures of perceived desirability, which is analogous to the concept of desire, namely, "How desirable is it for you to start your own business?" [15]. This appears to capture more of the personal attitude and value that is attached to starting a business, than a personal motivation. The desirability of entrepreneurship is determined, on the one hand, by beliefs relating to the consequences of creating a business and, on the other hand, by beliefs relating to the social environment $[16,17]$. However, Schlaegel and Koenig (2014) acknowledged that the desirability concept does not carry motivational content [5]. Ergo, there is no commitment towards a goal as yet. The definitions of desirability of entrepreneurship, without a doubt, reflect an attitude rather than a motivation.

The present study focused on examining the factors that explain the desirability of entrepreneurship and influence the intention to start a business as a long term and stable career opportunity. In this study, we regarded desirability of entrepreneurship as an expression of individuals' perceived entrepreneurial attitude and their willingness to start a business because they see it as a desirable career opportunity. Hence, understanding the factors that determine the desirability of entrepreneurship allows for a better understanding of the factors influencing entrepreneurial desire and intention. While similar studies have been conducted in the past, there is not enough evidence in the literature specific to the Romanian context. Earlier studies illustrate how the different 
personality characteristics and psycho-behavioral traits of individuals-such as creativity, locus of control, self-esteem, need for achievement, risk-taking propensity and subjective norms-influence entrepreneurial intentions $[18,19]$. Other studies investigate the extent to which access to finance explains differences in entrepreneurial activity [20]. The literature also includes studies that explain the underlying motivations that determine entrepreneurial intent and analyze the extent to which these motivations have cultural determinations [21]. Moreover, Dumitru and Dumitru (2017) investigated the institutional factors that explain a positive attitude to entrepreneurship, such as regulatory quality, government effectiveness, political stability, control of corruption, voice and accountability, rule of law, and labor market flexibility [9]. However, none of those studies investigate how the immediate socio-economic environment in which individuals live, are educated and work, affects their perception of entrepreneurship and, further, their attitude toward self-employment and desirability of entrepreneurship. The present study aimed to investigate what factors in the socio-economic environment of individuals determine their desirability of entrepreneurship and how these different factors further affect their desire to become an entrepreneur. It discussed the key determinants for the desirability of entrepreneurship in Romania by using the Amway Global Entrepreneurship Report dataset for this country.

A strong desirability of entrepreneurship and a sound desire to start a new venture can lead to sustainable job creation and sustainable business $[1,22,23]$. Sustainable job creation refers to building long-term, stable job opportunities to employment seekers and taking advantage of them. A sustainable business is the one that operates successfully in the economy for a long time. For this reason, in this paper, we argue that the increase of desirability of entrepreneurship can generate new, long-term, stable jobs, which are essential for socio-economic advancement.

The paper provides new evidence on the factors that determine the desirability of entrepreneurship and the willingness to start one's own business. Employing multiple linear regression, we found a positive relationship between "social stability", "feasibility", and "desirability of entrepreneurship" and a negative correlation with "age" and "comfort with acquiring customers". The present study contributes to the literature on the country-level determinants of desirability of entrepreneurship in three major ways. Firstly, to the best of our knowledge, this is the first study to examine the factors that determine the desirability of entrepreneurship, which may lead to greater entrepreneurial efficacy, fundamental to sustaining economic growth. Secondly, we contribute to the literature through expanding existing knowledge on the determinants of desirability of entrepreneurship using the factor "comfort with acquiring customers". Thirdly, we contribute to the literature by testing the influence of different individual-level and socio-demographic factors on the desirability of entrepreneurship.

\section{Literature Review}

\subsection{Framing the Desirability of Entrepreneurship and Entrepreneurial Intention}

Many studies on entrepreneurship acknowledge that entrepreneurial activity is the driving engine of sustainable development and economic progress. There are also studies that associate entrepreneurial activity with an insecure career path framed by a high level of risk and uncertainty. In this matter, a recent study by Kaiser and Moller (2011) of young Danish entrepreneurs proves that only $35.6 \%$ continued the entrepreneurship path after five years, others preferring to go back to working for a wage [24].

The concept of entrepreneurial intention is defined in the literature as a state of mind and a desire to create a new business or take up an activity [25,26]. Thompson (2009) defined entrepreneurial intentions as "self-acknowledged convictions by individuals that they intend to set up new business ventures and consciously plan to do so at some point in the future" [27] (p. 676). According to Ajzen (1991), the intentions of developing certain actions endorse any business or entrepreneurship decisions [16]. Referring to the Theory of Planned Behavior, the intention includes three important characteristics: a positive or negative attitude toward the matter; subjective norms or the social pressure 
to follow or not follow a certain behavior; and the individuals' self-control or self-efficacy, i.e., personal perception of their abilities to perform successfully [28]. The perceived entrepreneurial intention is expressed as readiness and determination to make every effort to start one's own business and carry out entrepreneurial behavior $[14,29,30]$. Wu and $\mathrm{Wu}(2008)$ argued that entrepreneurial intention is a determinant factor in predicting the effective business creation that requires both entrepreneurial feasibility perception and desirability [26].

The concept of perceived desirability to creating a new business has been examined in depth in the prevailing literature and used in entrepreneurial intention model formulations (e.g., $[14,15,31]$ ). Perceived desirability is the value associated with alternative wants and wishes at a pre-decisional phase [32]. The extant literature in the field of entrepreneurial path development $[14,15,30,33]$ defines the perceived desirability of entrepreneurship as willingness, anxiety and enthusiasm to start one's own business. According to Krueger (1993), desirability reflects the degree to which individuals value entrepreneurial behavior and find the prospect of becoming an entrepreneur to be attractive [14]. Entrepreneurial desirability is also regarded as the attitude of the individual toward a new venture creation [16] or attitudes toward action and social norms [34]. These studies use interchangeably the concepts of entrepreneurial desire and desirability of entrepreneurship.

Shapero and Sokol (1982) defined the perceived desirability of entrepreneurship as the extent to which one finds attractive the possibility of starting a business, and thus individuals display a positive entrepreneurial attitude [17]. They suggested that desirability is connected to personal values and career options, individuals with a high level of desirability displaying more enthusiasm about the creation of a new venture. The perception of desirability of entrepreneurship could be the reflection of one's internal standards of career options attractiveness as well as of external social pressures, market conditions, laws, etc. [35]. Following this idea, Vuorio et al. (2018) confirmed that the perceived entrepreneurial desirability is driven by intrinsic and extrinsic rewards [36]. Different individuals will have different perceptions of what they find desirable and feasible to accomplish. Fitzsimmons and Douglas (2011) defined the desirability of entrepreneurship as the degree of attractiveness that a person feels toward business creation and toward being an owner in an entrepreneurial company [37]. The authors emphasized that the entrepreneurial desirability is the individuals' perception of the net benefit they will gain from successfully running the business. Other research claims that the perceived desirability is concerned with the individual's beliefs about how likely is to have benefits through the successful creation of a new venture [38].

According to Barton et al. (2018), the term "perceived desirability" relates to how appealing it is to an individual to generate an entrepreneurial event such as starting a venture [39]. The level of perceived desirability varies based on individual characteristics and is affected by person's values, needs, skills and abilities. Riquelme and Al Lanqawi (2016) argued that the perceived desirability is a specific attitude that reflects "the valence (positive or negative) of an action's end state [ ... ] and does not have the connotation of a personal motivation to achieve an end state" [13] (p. 129). The authors framed the concept of perceived desire for entrepreneurship as internalized motivation or emotional response to the idea of self-employment, in criticism of Theory of Planned Behavior which emphasizes the importance of perceived desirability as the level of attractiveness and attitude toward entrepreneurship. In fact, the concept of "desire" defined by Bagozzi (1992) [40] equalizes the Gollwitzer's (1996) [32] construct of wishes or "volitional desires" as the driving engines of transforming certain attitudes and perceived desirability into intentions. The literature emphasizes that individuals who experience a high desirability of entrepreneurship tend to develop a high entrepreneurial intention and later behavior [39,41,42], desirability being a determinant predictor of entrepreneurial intention. Other research confirms the predictive power of perceived desirability and perceived feasibility on entrepreneurial intent formation $[43,44]$. The stronger id the desirability of entrepreneurship, the stronger is the intention toward that end objective.

Measuring the attitude toward entrepreneurship possibilities seems to be the best way to predict the value of the entrepreneurial intention [45]. In this regard, Dewberry and Duncan (2018) conducted 
a study of students' intention to drop out of college, using the Theory of Planned Behavior to predict the level of retention [6]. The main criteria were: attractiveness of course being studied (attitude toward object), perceived ability (self-efficacy), and other people's perspectives concerning course completion (subjective norms). The results were quite significant; the students' decision whether to give up college was determined by their attitude to the course, their self-efficacy, and their perception of important social norms. A similar mechanism can be seen functioning in the behavior of college graduates when it comes to entrepreneurial attitude and intention [46]. The results of research by Bo (2017) reveal that the attitude toward entrepreneurship is defined by business achievement expectations, a clear evaluation of the associated risk with the entrepreneurial actions, and the individual's personal qualities and abilities to succeed [47]. Moreover, research conducted by Ding and Choi (2011) in the academic field demonstrates that students or graduates who had a previous connection with the business environment in terms of common projects or patents have a positive attitude toward and perceived control of entrepreneurship intention [48]. In addition, entrepreneurship information and training support from the business environment tend to create a positive attitude toward entrepreneurship intention. Erikson (2003) argued that individuals form intentions toward something if they have a desire for the phenomenon and this phenomenon is perceived as being feasible, otherwise they are not likely to create it [49]. Having a desire for entrepreneurship, individuals have the opportunity to develop relevant abilities and skills and, therefore, their perception of entrepreneurial competence is a key determinant in manifesting their attitude to entrepreneurship. Therefore, it can be said in regard to entrepreneurship that there is a significant dialectical relationship between attitude (desirability) and intention [50].

The entrepreneurship literature identifies differences between individuals' abilities in recognizing innovative business opportunities, which translates into a positive attitude toward entrepreneurship and desirability of entrepreneurship [51]. Many academics do not have the necessary skills to pursue entrepreneurship behavior, since the skills acquired during college are very different from entrepreneurial skills [52]. There is a clear difference between experienced entrepreneurs and beginners when it comes to discovering entrepreneurial ideas, the latter lacking in scientific research and information-gathering abilities. On the contrary, people with a prior business environment connection have a confident attitude toward their prospects when starting a new venture, proving their positive attitude toward entrepreneurship intention and self-efficacy [50].

In their study, Saeed et al. (2015) explained the positive attitude toward entrepreneurship by referring to several psychological variables [53]. They analyzed important personal factors—such as creativity, perceived utility, self-efficacy and perceived control behavior, self-confidence, business experience, and the perception of a proper economic environment-to explain how these factors contribute to constructing a certain attitude to entrepreneurship. The study was a corollary to previous research by Fayolle and Linan (2014) [54], who identified two variables in the formation of the desire for entrepreneurship: individual variables referring to motivations, experience and personality traits; and contextual variables, such as market, economic and social context [55,56]. Moreover, the idea of contextual variables in defining entrepreneurship intentions appears in several studies $[57,58]$, which have emphasized the importance of young entrepreneurs acknowledging the latest government policies, logistic infrastructure, and financial support instruments as relevant factors in creating positive attitudes and behavior. Therefore, the desirability of entrepreneurship and the entrepreneurial desire and intention are key factors in understanding the entrepreneurial process; however, without a positive attitude, people will avoid going forward with transforming the intention into action, even when there is significant personal potential [15].

Thus, the desirability of entrepreneurship comes as a result of the influence of several factors, which will be further investigated in the paper. 


\subsection{Factors Affecting Desirability of Entrepreneurship and Entrepreneurial Intention}

Many entrepreneurship researchers have offered expectancy type and subjective-utility type models to describe the factors that influence people's desire and choice to follow an entrepreneurial path $[55,59]$. The models describe the individuals' perceptions about income prospects, the effort associated with achieving the necessary performance to reach the monetary benefits predicted, the amount of risk implied, and the craving for independence. Recent studies reveal a huge gap between desire and intention, on the one hand, and actions to reach the framed objectives, on the other hand [60]. For psychologists Gollwitzer and Heckhausen (1987), the difficulties in pursuing an entrepreneurship career even when strongly motivated are due to a lack of individual characteristics-precisely, the element of volition [61]. According to Broonen (2010), volition is the process that determines the transition from intention to action [62].

The transition of entrepreneurship from desirability to desire and intention and successfully to action requires resistance to uncertainty, defined as the ability to successfully overcome the tension created by external factors that sometimes can delay or change the entrepreneurship pace [63]. People who have already framed their desirability of entrepreneurship and the entrepreneurial desire and intention (proving self-motivation) would have higher chances of succeeding compared with those who have not.

Various studies in the literature examine different factors that influence people's perception of their entrepreneurial intention and their proclivity to start their own business. A study developed by Failla et al. (2017) demonstrates that entrepreneurship is an important factor in obtaining job stability [64]. The research is based on the analysis of three mechanisms that influence individuals' employment turnover rate: job matching, labor market value, and personal commitment. The jobmatching model indicates a high tendency towards independence, desire for extra income, and a taste for challenge and variety. The evidence shows a negative effect on entrepreneurs returning to salaried work-first, by receiving fewer job offers and, second, by having their entrepreneurship experience and skills undervalued [65]. The study also reveals the entrepreneurs' personal commitment to their company even when faced with poor business performance. The psychological reasons for delaying the moment of leaving the entrepreneurial activities refer to attachment to the values of the company or the entrepreneur's perception of indispensability [66].

Referring to the academic environment, Goethner et al. (2012) concluded clear influence of family, friends, or co-workers as subjective norm factors in defining the entrepreneurial intention of individuals who activate within universities [51]. According to their study, people adopt positive attitudes toward entrepreneurial ideas and perceive entrepreneurship as being desirable as long as the prospects perceived are professionally stimulating, along with financially rewarding. In addition, other research identifies academic promotion as key to framing the desirability of entrepreneurship in the academic field, endorsed by psychological variables such as scientific productivity and entrepreneurship self-identity [55].

The process of increasing the perception of attractiveness toward the idea of investing in a new venture has a direct impact on entrepreneurial intentions [67]. According to Van Kleef (2009), emotional expressions have important social functions, influencing attitudes towards certain perspectives or issues [68]. In contrast, the fear of failure represents an inhibitory factor in entrepreneurship, acting like a barrier to transforming intention into action [69]. However, research evidence shows the possibility of motivating and driving entrepreneurship behavior [70]. The entrepreneurial motivating factors such as dedication, confidence, social-recognition, or self-efficacy have proved their positive-oriented behavior. Conversely, lack of confidence and risk aversion work as inhibitors on entrepreneurial behavior [71]. According to Cacciotti et al. (2016), individuals tend to put more effort and commitment into entrepreneurship projects to avoid unsuccessful and shameful outcomes [72].

A considerable part of the literature offers results that refer to the importance of entrepreneurship education and the positive relationship between the desire to pursue an entrepreneurship path and the level of education [73]. The research emphasizes the responsibility of educational institutions to 
provide the necessary courses as baselines for developing problem-solving skills and self-confidence. The study by Mamabolo et al. (2017) on entrepreneurship skills required in emergent-economy countries proves that, with continuous preparation and entrepreneurship training, even in a poor educational system, the desirability of entrepreneurship and feasibility increase [74]. The research shows also the significance of knowledge and skills in domains such as financial management, leadership, marketing, technical skills, and business management.

Recently, the Program for the International Assessment of Adults Competencies (https:/ /nces. ed.gov/surveys/piaac/) published the results of a study referring to entrepreneurship feasibility. The program revealed that $20 \%$ of European students were overqualified to work for other companies, but were lacking in leadership, negotiation, and communications skills, which are necessary skills for launching a new venture. Therefore, the European Union Horizon 2020 developed entrepreneurship programs designed to expand the entrepreneurial abilities to specific population groups, based on educational strategies such as active learning, simulations, and social learning, to narrow the gap between theoretical knowledge and real-life experience [2].

Entrepreneurship activity, whether social or regular business activity, requires a well-determined set of competencies and skills for reaching a sustainable level of performance $[75,76]$. There are different debates related to defining skills and competencies necessary for the entrepreneurial activity. Using a broader approach, many scholars agree that competencies are defined as the integration of the individual's skills, abilities, knowledge, and motivation to pursue and run a stable and continuous business venture [77]. Competencies include different skills in performing all types of tasks. Therefore, in entrepreneurship, defining the necessary skills and competencies is challenging [78]. Studies refer to four skill dimensions, including both meta-level skills or abstract skills and those referring to the functional aspects of a business: entrepreneurial skills, managerial abilities, technical skills, and personal maturity skills [74,79]. Other studies bring to attention the marketing and management abilities and skills as being essential in the entrepreneurial activity and financial skills particularly necessary in the maturity stage of the business venture [80]. This is highly important if we consider that entrepreneurs as self-employed are paid by their customers and, therefore, they should have the ability to acquire and retain their own customers. For other scholars [81], a high level of adaptation to uncertain situations, leadership, data gathering and information represent high-level skills, whereas for others active listening, negotiation techniques, risk taking, and innovation are the most important "traits" for a meta-skilled entrepreneur [82]. Recent research includes as important determinants of a future entrepreneur the ability to recognize opportunities, strategic planning skills, and teamwork skills, along with creative thinking and interpersonal skills $[83,84]$.

A considerable part of the research associates entrepreneurial activity with sustainable development and corporate social responsibility, identifying common competencies and skills required to act as a change agent of the society in general [85]. Different frameworks of skills and competencies were developed and tested in the work environment based on four dimensions of sustainability competence: knowledge, critical thinking, innovation or change dimension, and ethical criteria [86]. According to Lans et al. (2014), the entrepreneurial competence framework includes seven key competencies and skills-namely, interdisciplinary competences, system-thinking abilities, "outside of the box" thinking, normative competences, action and decision-making abilities, interpersonal skills, and strategic management competences [87]. Although these competencies have been tested and operationalized in the working environment, many scholars consider them too general, the research being at the exploratory level only [88].

There is no united "voice" that states education is a mandatory determinant of entrepreneurship. Several studies have concluded a positive relationship between education and the probability of entrepreneurship [89]. However, several studies in developing countries reveal that education has no influence on the entrepreneurial decision [90]. Although a superior level of managerial skills and education may impart the ability to find opportunities, forecast trends, and lead others, many 
individuals from developed countries select regular employment as their first choice, instead of the entrepreneurial path [91].

The research by Stefanović and Stošić (2012), referring to a self-employed population from the Republic of Serbia, reveals that $48.4 \%$ of Serbian entrepreneurs were high-school graduates, $25.3 \%$ of the self-employed population barely completed primary school, while only $10.8 \%$ of the total number of entrepreneurs had college or university degrees [92]. This phenomenon is explained by the theory that people choose entrepreneurship because they are unemployed or are working in unsatisfactory conditions. Recent research indicates that people with a lower level of competencies become entrepreneurs out of necessity, whereas highly skilled individuals choose self-employment out of opportunity [93]. Studies referring to the importance of education on the probability of entrepreneurship bring to attention the diversity of occupations and industries in which self-employed people are active. According to Bates (1995), education has a positive effect on entrepreneurial professional services, and a negative effect on the construction industry [94]. Studies also reveal big differences in the impact of education on entrepreneurship between the USA and Europe-namely, that a high level of education translates into a positive impact on the choice of self-employment among Americans, while Europeans with the same level of education prefer paid employment, especially in developing countries [92].

The dynamic of self-employment and entrepreneurship activity is influenced also by age. A strong body of literature has launched different theories and studies on the appropriate age for entrepreneurship. Studies show that financial and non-financial resources increase with age; therefore, individuals are more inclined to take the entrepreneurship path [95]. People of a certain age have already created their networks of possible stakeholders, added to their professional and working experience, and created strong determinants for self-realization. However, it is proved that the ability to assume risk decreases with age, people being more cautious when giving-up their paid job for uncertain gains in the future [95]. The research by Praagh and Ophem (1995) makes a clear difference between people who have the desire to take an entrepreneurial course of business action but lack the resources, and those who have the necessary skills, relations, and financial backing, but a low level of motivation due to age [90]. Several studies found that the willingness for entrepreneurship increases with age but only to a certain point; after that, the desirability of entrepreneurship fades away, despite confirmed opportunities and resources [96]. The age limit above which individuals become less interested in launching a new venture varies between countries and different economic and political systems. According to Moore and Mueller (2002), people reaching middle age are more inclined to follow an entrepreneurial idea and decision [89].

Levels of education, age, income, skills, and employment status are referred to as strong determinants for entrepreneurship willingness and decision, which underscores the importance of a reliable and supportive institutional and governmental environment. In fact, a recent study reveals three important determinants that contribute to the entrepreneurship and self-employment decision: personal, institutional, and contextual [97]. The personal factors agree with the positive impact of work experience and education in supporting business ventures. The institutional factors bring to attention the importance of existing non-governmental institutions that allow entrepreneurs to access financial and non-financial resources along with contextual factors such as business opportunities and favorable rules and regulations. According to Lee et al. (2011), the policies dedicated to entrepreneurial activities must be concentrated on rules concerning maximizing the opportunities of profit and community gains by, on the one hand, reducing entry barriers and antitrust regulations and, on the other hand, minimizing the possibility of failure by modifying the bankruptcy regulations for the entrepreneurs' benefit [98]. Consequently, there is a wide range of contextual and situational factors which can predict the entrepreneurship pace, in different stages, starting from manifesting desirability, creating desire and moving forward to developing entrepreneurial intention. 


\section{Methodology}

\subsection{Hypotheses Development}

Earlier studies $[6,28,45,46]$ imply a strong relation between feasibility and entrepreneurial proclivity, translated into individuals' efforts to properly assess their abilities to provide the necessary resources or complete specific entrepreneurial tasks. Determinants of positive attitude to entrepreneurship and, accordingly, of entrepreneurship desirability refer not only to business achievement expectations, risk assessment, and perceived self-control [47], but also to certain skills, proper training and information [64]. The perceived feasibility of entrepreneurship brings to attention the importance of the moment of internalizing certain abilities and skills to assume more challenges and, therefore, according to Mau (2003) [99], to reinforce the perception of self-efficacy into a spiral effect, increasing the probability of entrepreneurship intention. Based on these arguments, our first hypothesis states that:

Hypothesis 1. The feasibility of entrepreneurship is positively related to the desirability of entrepreneurship.

In their recent study, Saeed et al. (2015) [53] revealed the perception of a proper economic environment as the key determinant of a positive attitude toward entrepreneurship. Fayolle and Linan (2014) [54] identified two variables that contribute to desirability of entrepreneurship and further to entrepreneurial intention-namely, individual variables (motivation, experience, and personal traits) and contextual variables (market volatility, economic context, social environment, and family). The research by Davaria and Farokhmaneshb (2017) [97] emphasizes the importance of institutional and governmental bodies sustaining entrepreneurship ideas by facilitating easier access to financial and non-financial resources, along with implementing favorable rules and regulations regarding new ventures, which are meant to ensure a proper socio-economic environment. Based on the arguments presented, our second hypothesis is formulated as follows:

Hypothesis 2. The social stability is positively related to the desirability of entrepreneurship.

The term entrepreneurship is often associated with sustainable business development, where key competencies are required. Lans et al. (2014) [87] inferred the importance of interpersonal skills, translated as communication and leadership abilities, flexibility, and competencies related to gaining and retaining clients, as entrepreneurs are directly paid by customers. The desire to follow the entrepreneurship path is highly determined by self-confidence, self-efficacy, and a genuine sense of accomplishment. Significant studies in the academic area regarding desirability of entrepreneurship reveal the positive attitude of students involved in different collective projects, and their strong willingness to cooperate and to involve more individuals [48]. Recent studies by Mosey and Wright (2007) [52] prove a clear difference between people with prior business experience and beginners when it comes to the desirability of entrepreneurship, the first category being already accustomed to clients' acquirement process and other managerial duties than the others. Therefore, our third hypothesis states that:

Hypothesis 3. The higher is the comfort with acquiring customers, the stronger is the desirability of entrepreneurship.

Scholars generally agree that age is an important determinant of the desirability of entrepreneurship, although debates related to positive or negative influence still stand. According to Parker (2005) [95], people reaching middle age should be in favor of the entrepreneurship path, motivated by superior financial and non-financial resources, managerial experience, and probably a well-established stakeholders' network compared to younger individuals. Following this idea, Praagh and Ophem (1995) [90] divided entrepreneurs into those who have a strong desire for self-employment but lack the necessary resources and those who have the pre-condition to launch a new venture but their level 
of desire is quite low due to their age. With age, people become more resilient against risks and uncertainty. The research of Paunescu and Blid (2017) [96] on senior entrepreneurs from Romania also reveals that the desirability of entrepreneurship increases with age up to a point, after which the rate decreases with ageing, despite the existence of certain resources and abilities. However, Moore and Mueller (2002) [89] demonstrated in their study that people reaching middle age are more interested in launching new ventures. Based on the arguments presented, our fourth hypothesis posits that:

Hypothesis 4 . The higher is the age, the lower is the desirability of entrepreneurship.

Education, income, age and social status are strong determinants of the desirability of entrepreneurship. Several studies [74,78-80] maintain that a higher level of education is a significant factor in entrepreneurship decisions. Sustainable ventures require planning, as well as managerial, technical, and interpersonal abilities, which can be acquired through continuous study and preparation. Research by Mamabolo et al. (2017) [74] confirms that, even in emergent economies with poor educational systems, entrepreneurship courses increase desirability of entrepreneurship and entrepreneurial intention. Following the same idea, research conducted by Diaz-Garcia (2015) [100] in the academic field proves a higher interest in desirability of entrepreneurship in students after completing an entrepreneurship course. However, research undertaken by Stefanović and Stošić (2012) [92] on Serbian people demonstrates that the educational factor had no relevance on "out-of-necessity" desirability of entrepreneurship. Sluis et al. (2005) [91] related a high level of education to the ability to find new opportunities, to analyze trends, and to lead working teams, all significant qualities for launching a sustainable business. Moreover, research conducted by Bates (1995) [94] reveals a positive impact of education on entrepreneurship professional services and a less positive relation between academic studies and the construction industry. A more recent study conducted by Fellnhofer (2018) indicates that individuals' perceptions of the desirability of entrepreneurship and the entrepreneurial intention are significantly different before and after exposure to entrepreneurial narratives [30]. Hence, desirability of entrepreneurship could also be affected through education [34]. Social support for entrepreneurship coming from relevant sources (possibly educational programs) could increase the desirability of entrepreneurship [13]. Based on the results of the studies presented, the fifth hypothesis infers:

Hypothesis 5. The higher is the level of education, the stronger is the desirability of entrepreneurship.

The desire to enter the business environment is highly influenced by the level of income. Extended to academic research, the study by Goethner et al. (2012) [51] shows that people's desire for and positive attitude toward entrepreneurship is highly influenced by the prospect of professional and material gains. Deli (2011) [93] emphasized out-of-necessity motivation for choosing the entrepreneurship path with financial stability as a significant determinant. Other studies $[64,101]$ refer to the connectivity between self-employment intention and job-matching criteria, including professional satisfaction and financial stability. Based on the arguments presented, the sixth hypothesis states that:

Hypothesis 6. The lower is the income, the higher is the desirability of entrepreneurship.

Several studies $[70,72]$ associate the motivation for entrepreneurship with the fear of failure, which is an inhibiting factor for self-employment and entrepreneurship. These studies indicates that the possibility of an unsuccessful business creates the fear of losing social or working status. However, other researchers $[88,90,92]$ argue that people think more to existing alternatives, make choices regarding their career path and take entrepreneurship decisions due to being unemployed or in unsatisfactory employment conditions. Therefore, the seventh hypothesis states that:

Hypothesis 7. There is a statistically significant effect of working status on the desirability of entrepreneurship. 


\subsection{Research Objectives and Method}

The paper aims to examine the factors that determine the perceived desirability of entrepreneurship and how these different factors further affect the desire to become an entrepreneur. The paper's objectives are as follows: (1) to understand the key determinants of the desirability of entrepreneurship and how well they can predict desirability; (2) to identify the best predictor of the desirability of entrepreneurship amongst our set of variables; and (3) to determine whether a particular variable is still able to predict the desirability of entrepreneurship when the effects of another variable are controlled for.

The paper uses the Amway Global Entrepreneurship Report (AGER) dataset for 2016 to examine the determining factors of desirability of entrepreneurship in Romania. Data include 1023 responses collected based on a global survey run in 2016 through face-to-face or telephone interviews, by using a fully structured questionnaire. In this paper, we examine the perceived desirability of entrepreneurship of Romanian respondents by taking into consideration the variables indicated by the theory as being significant predictors of desirability and which further influence entrepreneurial desire and intention. These variables include feasibility of entrepreneurship [74,78,80], social stability $[46,68]$, and comfort with acquiring customers [71,84] as strong predictors of desirability of entrepreneurship, as well as socio-demographic factors such as: age [92,96], gender [79], education [92,100], income level [24], and working status $[64,65,89,93]$. According to AGER, desirability of entrepreneurship is expressed as desire to become an entrepreneur. Desirability measures whether respondents perceive starting a business and becoming self-employed as favorable. AGER does not distinguish between the terms "desire for entrepreneurship" and "desirability of entrepreneurship". However, in this paper, "desirability of entrepreneurship" measures individuals' perceived entrepreneurial attitude and their perceptions about willingness to start a business as a desirable career opportunity. "Feasibility of entrepreneurship" measures individuals' perceptions about possessing the necessary skills, capabilities, and resources needed to start a business. "Social stability" assesses whether individuals would let their social environment (family and friends) dissuade them from starting a business. "Comfort with acquiring customers" assesses the individuals' perceived preparedness to identify, acquire, and retain customers as a self-employed person.

A multiple linear regression model was employed to describe the relationship between two or more explanatory variables and a response variable by fitting a linear equation to observed data. Regression is particularly useful to understand the predictive power of the independent variables on the dependent variable once a causal relationship has been confirmed. Every value of the independent variable $x$ is associated with a value of the dependent variable $y$. The population model for a multiple linear regression model that relates a $y$-variable (outcome or dependent variable), in our case desirability of entrepreneurship, to $r x$-variables ( $\mathrm{r}$ distinct independent or predictor variables), is written as:

$$
y_{\mathrm{i}}=\beta_{0}+\beta_{1} x_{\mathrm{i}, 1}+\beta_{2} x_{\mathrm{i}, 2}+\ldots+\beta_{\mathrm{r}} x_{\mathrm{i}, \mathrm{r}}+\varepsilon_{\mathrm{i}}
$$

$\beta_{1}$ through $\beta_{\mathrm{r}}$ are the estimated regression coefficients while $\varepsilon_{\mathrm{i}}$ represents the residual (error) term. Each $\beta$ coefficient represents the change in the mean response per unit increase in the associated predictor variable when all other predictors are held constant. For example, $\beta_{1}$ represents the change in the mean response per unit increase in $x_{1}$, when $x_{2}, x_{3}, \ldots x_{\mathrm{r}}$ are held constant (i.e., when the remaining independent variables are held at the same value or are fixed). The subscript $i$ refers to the $i$ th individual or unit in the population. The intercept term, $\beta_{0}$, represents the mean response, when all predictors, $x_{1}, x_{2}, \ldots, x_{\mathrm{r}}$, are zero. The residual (error) $\varepsilon_{\mathrm{i}}$ is calculated as the difference between an actual and a predicted value of dependent variable.

\section{Results}

The following section provides a concise description of our regression model and interpretation of the results. 


\section{Regression Analysis of the Desirability of Entrepreneurship}

Multiple regression is conducted to determine the overall fit (variance explained) of the model, whether the variables selected are significant predictors of the perceived desirability of entrepreneurship, and the relative contribution of each of the predictors to the total variance explained. Multiple regression is also employed to measure whether including an additional variable makes a difference, and to control for other variables when exploring the predictive ability of the model. We use linear regression to understand whether the desirability of entrepreneurship can be predicted based on feasibility of entrepreneurship, stability against family and social pressure, and comfort with acquiring customers, as well as based on demographic factors such as: age, gender, education, income level, and working status. The multiple linear regression equation is as follows:

$$
\text { Des }=\beta_{0}+\beta_{1} \text { Feas }+\beta_{2} \text { Stab }+\beta_{3} \operatorname{Comf}+\beta_{4} \text { Age }+\beta_{5} \text { Sex }+\beta_{6} \text { Edu }+\beta_{7} \text { MHNI }+\beta_{9} \text { Work }+\varepsilon
$$

where Des is the desirability of entrepreneurship, which represents the dependent variable. The control variables are: Age (age); Sex (gender); Edu (education); and MHNI (Monthly Household Net-Income). The predictor variables are: Feas (feasibility of entrepreneurship); Stab (social stability); Comf (comfort with acquiring customers); Age (age); Sex (gender); Edu (education); MHNI (Monthly Household Net-Income); and Work (working status).

To ensure that the linear regression can offer us a valid result, we checked the data to make sure they can be analyzed using linear regression. Firstly, we checked if there was a linear relationship between our variables by creating a scatterplot. The scatter plot indicates a good linear relationship. We also checked the Pearson's correlation (Table 1). Our findings show that most of our variables are significantly correlated, except for gender, which is not significant $(\mathrm{r}=-0.057$ with $p=0.066$ higher than the threshold for significance of 0.05 ). Therefore, we decided to exclude this variable from the analysis.

Table 1. Pearson's correlations.

\begin{tabular}{|c|c|c|c|c|c|c|c|c|c|c|}
\hline & & Deas & Feas & Stab & Comf & Age & Sex & $E d u$ & $M N I$ & Work \\
\hline \multirow{3}{*}{ Des } & Pearson Correlation & 1 & $0.448^{* *}$ & $0.499 * *$ & $-0.375^{* *}$ & $-0.371^{* *}$ & -0.057 & $0.163 * *$ & $0.241 * *$ & $-0.214^{* *}$ \\
\hline & Sig. (two-tailed) & & 0.000 & 0.000 & 0.000 & 0.000 & 0.066 & 0.000 & 0.000 & 0.000 \\
\hline & $\mathrm{N}$ & 1023 & 1023 & 1023 & 782 & 1023 & 1023 & 1023 & 733 & 1023 \\
\hline \multirow{3}{*}{ Feas } & Pearson Correlation & $0.448^{* *}$ & 1 & $0.376 * *$ & $-0.318^{* *}$ & $-0.233 * *$ & $-0.099 * *$ & $0.171^{* *}$ & $0.227^{* * *}$ & $-0.189^{* *}$ \\
\hline & Sig. (two-tailed) & 0.000 & & 0.000 & 0.000 & 0.000 & 0.002 & 0.000 & 0.000 & 0.000 \\
\hline & $\mathrm{N}$ & 1023 & 1023 & 1023 & 782 & 1023 & 1023 & 1023 & 733 & 1023 \\
\hline \multirow{3}{*}{ Stab } & Pearson Correlation & $0.499^{* *}$ & 0.376 ** & 1 & $-0.366^{* *}$ & $-0.280 * *$ & -0.055 & $0.161^{* *}$ & $0.254^{* * *}$ & -0.174 ** \\
\hline & Sig. (two-tailed) & 0.000 & 0.000 & & 0.000 & 0.000 & 0.080 & 0.000 & 0.000 & 0.000 \\
\hline & $\mathrm{N}$ & 1023 & 1023 & 1023 & 782 & 1023 & 1023 & 1023 & 733 & 1023 \\
\hline \multirow{3}{*}{ Comf } & Pearson Correlation & $-0.375^{* *}$ & $-0.318^{* *}$ & $-0.366^{* *}$ & 1 & $0.306^{* *}$ & 0.021 & -0.069 & $-0.146^{* *}$ & $0.156^{* *}$ \\
\hline & Sig. (two-tailed) & 0.000 & 0.000 & 0.000 & & 0.000 & 0.564 & 0.053 & 0.001 & 0.000 \\
\hline & $\mathrm{N}$ & 782 & 782 & 782 & 782 & 782 & 782 & 782 & 561 & 782 \\
\hline \multirow{3}{*}{ Age } & Pearson Correlation & $-0.371 * *$ & $-0.233^{* *}$ & $-0.280 * *$ & $0.306^{* *}$ & 1 & -0.034 & $-0.152 * *$ & $-0.259 * *$ & $0.344^{* *}$ \\
\hline & Sig. (two-tailed) & 0.000 & 0.000 & 0.000 & 0.000 & & 0.277 & 0.000 & 0.000 & 0.000 \\
\hline & $\mathrm{N}$ & 1023 & 1023 & 1023 & 782 & 1023 & 1023 & 1023 & 733 & 1023 \\
\hline \multirow{3}{*}{ Sex } & Pearson Correlation & -0.057 & $-0.099 * *$ & -0.055 & 0.021 & -0.034 & 1 & -0.034 & $-0.083 *$ & 0.057 \\
\hline & Sig. (two-tailed) & 0.066 & 0.002 & 0.080 & 0.564 & 0.277 & & 0.274 & 0.025 & 0.067 \\
\hline & $\mathrm{N}$ & 1023 & 1023 & 1023 & 782 & 1023 & 1023 & 1023 & 733 & 1023 \\
\hline \multirow{3}{*}{$E d u$} & Pearson Correlation & $0.163 * *$ & $0.171 * *$ & $0.161^{* *}$ & -0.069 & $-0.152 * *$ & -0.034 & 1 & $0.429 * *$ & $-0.368^{* *}$ \\
\hline & Sig. (two-tailed) & 0.000 & 0.000 & 0.000 & 0.053 & 0.000 & 0.274 & & 0.000 & 0.000 \\
\hline & $\mathrm{N}$ & 1023 & 1023 & 1023 & 782 & 1023 & 1023 & 1023 & 733 & 1023 \\
\hline \multirow{3}{*}{ MHNI } & Pearson Correlation & $0.241^{* *}$ & $0.227 * *$ & $0.254 * *$ & $-0.146 * *$ & $-0.259 * *$ & $-0.083 *$ & $0.429 * *$ & 1 & $-0.445 * *$ \\
\hline & Sig. (two-tailed) & 0.000 & 0.000 & 0.000 & 0.001 & 0.000 & 0.025 & 0.000 & & 0.000 \\
\hline & $\mathrm{N}$ & 733 & 733 & 733 & 561 & 733 & 733 & 733 & 733 & 733 \\
\hline \multirow{3}{*}{ Work } & Pearson Correlation & $-0.214^{* *}$ & $-0.189^{* *}$ & $-0.174 * *$ & $0.156^{* *}$ & $0.344^{* *}$ & 0.057 & $-0.368^{* *}$ & $-0.445^{* *}$ & 1 \\
\hline & Sig. (two-tailed) & 0.000 & 0.000 & 0.000 & 0.000 & 0.000 & 0.067 & 0.000 & 0.000 & \\
\hline & $\mathrm{N}$ & 1023 & 1023 & 1023 & 782 & 1023 & 1023 & 1023 & 733 & 1023 \\
\hline
\end{tabular}

Note: Des, desirability of entrepreneurship; Feas, feasibility of self-employment; Stab, stability against social pressure; Comf, comfort with acquiring customers; Age, age; Sex, gender; Edu, education; MHNI, monthly household net-income; Work, working status. Source: Authors' computation. ${ }^{* *}$ correlation is significant at the 0.01 level (two-tailed); ${ }^{*}$ correlation is significant at the 0.05 level (two-tailed). 
We performed regression analysis by using the Enter method of regression. We explored the causal relationship between two or more variables and their predictive power while statistically controlling for another variable. We suspected that the relationship between variables may be influenced, or confounded, by the impact of other variables. The variables normally controlled for are socio-demographic variables such as age, education, and income. The descriptive statistics and correlations between our variables are shown in Table 2 .

Table 2. Mean, standard deviation and Pearson's correlations.

\begin{tabular}{|c|c|c|c|c|c|c|c|c|c|c|c|}
\hline & Mean & SD & $\mathbf{N}$ & Des & Age & $E d u$ & MHNI & Feas & Stab & Comf & Work \\
\hline Des & 0.35 & 0.476 & 1023 & 1.000 & & & & & & & \\
\hline Age & 44.93 & 17.215 & 1023 & $-0.371 * * *$ & 1.000 & & & & & & \\
\hline$E d u$ & 2.98 & 0.692 & 1023 & $0.163^{* * *}$ & $-0.152^{* * *}$ & 1.000 & & & & & \\
\hline Feas & 0.21 & 0.410 & 1023 & $0.448^{* * *}$ & $-0.233^{* * *}$ & $0.171^{* * *}$ & $0.227^{* * *}$ & 1.000 & & & \\
\hline Stab & 0.45 & 0.497 & 1023 & $0.499^{* * *}$ & $-0.280 * * *$ & $0.161^{* * *}$ & $0.254^{* * *}$ & $0.376^{* * *}$ & 1.000 & & \\
\hline Comf & 2.54 & 0.951 & 782 & $-0.375^{* * *}$ & $0.306^{* * *}$ & $-0.069 *$ & $-0.146^{* * *}$ & $-0.318^{* * *}$ & $-0.366^{* * *}$ & 1.000 & \\
\hline
\end{tabular}

Source: Authors' computation. ${ }^{* * *}$ Sig. (one-tailed) $<0.001 ; *$ Sig. (one-tailed) $<0.05 ;$ SD, standard deviation.

The mean score for social stability close to the middle point $(\mathrm{x}$ bar $=0.45, \mathrm{SD}=0.497$ ) tells us that this variable highly accounts for increasing the perceived desirability of entrepreneurship in comparison with feasibility, which seems to have a low influence on the decision to start a business $(\mathrm{x}$ bar $=0.21, \mathrm{SD}=0.410)$. In addition, the mean score for comfort with acquiring customers of 2.54 means that, on average, our sample of respondents feel rather uncomfortable when it comes to identifying and retaining customers. Furthermore, the mean scores for education, net income and working status mean that respondents in the sample completed at least secondary or high school, earn about 400 euro per month, on average, and are basically part-time employed. In addition, the values of standard deviation in the statistical dataset close to the mean indicate these variables are highly reliable. The predictor variables that account for a stronger significant correlation with the perceived desirability of entrepreneurship are: social stability $(\mathrm{r}=0.499, p<0.001)$, feasibility $(\mathrm{r}=0.448, p<0.001)$, comfort with acquiring customers $(\mathrm{r}=-0.375, p<0.001)$ and age $(\mathrm{r}=-0.371, p<0.001)$. All requested variables entered the model.

The model summary is presented in Table 3. There are two models listed. Model 1 refers to the control variables, namely "age", "education" and "income", while Model 2 includes all the predicting variables of the perceived desirability of entrepreneurship: "age", "education", "income", "working status", "social stability", "feasibility", and "comfort with acquiring customers". Checking the R square value in the third column, after the variables in Block 1 have been entered, Model 1 explains 16.3\% of the variance, while Model 2 that includes all seven variables explains $38.4 \%$ of the overall variance in the perceived desirability of entrepreneurship. To establish how much of this overall variance is explained by our variables of interest after the effects of age, education and income are removed, we look at the column labeled $R$ square change $\left(\Delta R^{2}\right)$. The overall variance explained by the $R$ square change after remove of control variables explain additional $22.1 \%$ significant amount of variance. This means that "feasibility", "social stability", "comfort with acquiring customers" and "working status" explain an additional $22.1 \%$ of the perceived "desirability of entrepreneurship", even when statistically controlling for the effects of age, education and income. This is statistically significant contribution, as indicated by the Sig. F Change value for this line (0.001). The Durbin-Watson $d=1.847$, which is between the two critical values of $1.5<\mathrm{d}<2.5$, tells us that there is no first-order linear auto-correlation in our multiple linear regression data and the model has a good fit. 
Table 3. Model summary for the desirability of entrepreneurship ${ }^{c}$.

\begin{tabular}{|c|c|c|c|c|c|c|c|c|c|c|}
\hline \multirow{2}{*}{ Model } & \multirow{2}{*}{$\mathbf{R}$} & \multirow{2}{*}{$\mathbf{R}^{2}$} & \multirow{2}{*}{ Adjusted $R^{2}$} & \multirow{2}{*}{ SE } & \multicolumn{5}{|c|}{ Change Statistics } & \multirow{2}{*}{ Durbin-Watson } \\
\hline & & & & & $\Delta \mathbf{R}^{2}$ & $\Delta \mathrm{F}$ & df1 & df2 & Sig. F Change & \\
\hline 1 & $0.404^{\mathrm{a}}$ & 0.163 & 0.159 & 0.436 & 0.163 & 36.204 & 3 & 557 & 0.000 & \multirow{2}{*}{1.847} \\
\hline 2 & $0.620^{b}$ & 0.384 & 0.377 & 0.376 & 0.221 & 49.685 & 4 & 553 & 0.000 & \\
\hline
\end{tabular}

Source: Authors' computation. Note: a Predictors (Constant): MHNI, Age, Edu; ${ }^{\mathrm{b}}$ Predictors (Constant): MHNI, Age, Edu, Feas, Comf, Stab, and Work; ${ }^{c}$ Dependent variable: Des.

The ANOVA results in Table 4 show that all our variables are significant predictors of the desirability of entrepreneurship (Model 2: $\mathrm{F}=49.332, p<0.001$ ), and that the model has a good fit.

Table 4. ANOVA results for the desirability of entrepreneurship ${ }^{\mathrm{a}}$.

\begin{tabular}{ccccccc}
\hline & Model & Sum of Squares & df & Mean Square & F & Sig. \\
\hline \multirow{2}{*}{$\mathbf{1}$} & Regression & 20.671 & 3 & 6.890 & 36.204 & $0.000^{\mathrm{b}}$ \\
& Residual & 106.010 & 557 & 0.190 & & \\
& Total & 126.681 & 560 & & & \\
\hline \multirow{2}{*}{$\mathbf{2}$} & Regression & 48.697 & 7 & 6.957 & 49.332 & $0.000^{\mathrm{c}}$ \\
& Residual & 77.984 & 553 & 0.141 & & \\
& Total & 126.681 & 560 & & &
\end{tabular}

Source: Authors computation. Note: ${ }^{a}$ Dependent variable: Des; ${ }^{b}$ Predictors (Constant): MHNI, Age, Edu; ${ }^{c}$ Predictors (Constant): MHNI, Age, Edu, Feas, Comf, Stab, and Work.

To find how well each of the variables predicts the dependent variable, we looked at the coefficients (Table 5). The coefficients (Model 2 ) show that stability against social pressure $(b=0.286, p<0.001)$ and feasibility of entrepreneurship $(b=0.280, p<0.001)$ are significant and positive predictors of the perceived desirability of entrepreneurship, whilst comfort with acquiring customers $(b=-0.063$, $p<0.001)$ and age $(b=-0.005, p<0.001)$ are significant but negative predictors of the perceived desirability of entrepreneurship. The level of education, monthly income level and working status seem not to be significant predictors of the perceived desirability of entrepreneurship. In addition, our model of regression shows that a 1-unit increase in stability against social pressure will result in 0.286 unit increase in desirability of entrepreneurship and a 1-unit increase in feasibility will result in 0.280 unit increase in desirability of entrepreneurship. Therefore, hypotheses $\mathrm{H} 1$ and $\mathrm{H} 2$ have been confirmed. On the other hand, a 1-unit increase in discomfort with searching for, acquiring, and retaining customers will generate 0.063 unit decrease in desirability of entrepreneurship and a 1-unit increase in age will produce 0.005 unit decrease in desirability of entrepreneurship. As such, hypotheses $\mathrm{H} 3$ and $\mathrm{H} 4$ have been successfully confirmed. 
Table 5. Coefficients ${ }^{\mathrm{a}}$.

\begin{tabular}{|c|c|c|c|c|c|c|c|c|c|c|}
\hline & \multirow{2}{*}{ Model } & \multicolumn{2}{|c|}{$\begin{array}{c}\text { Unstandardized } \\
\text { Coefficients }\end{array}$} & \multirow{2}{*}{$\begin{array}{c}\begin{array}{c}\text { Standard. } \\
\text { Coefficients }\end{array} \\
\text { Beta }\end{array}$} & \multirow{2}{*}{$\mathbf{t}$} & \multirow{2}{*}{ Sig. } & \multicolumn{2}{|c|}{$\begin{array}{l}95.0 \% \text { Confidence } \\
\text { Interval for B }\end{array}$} & \multicolumn{2}{|c|}{$\begin{array}{l}\text { Collinearity } \\
\text { Statistics }\end{array}$} \\
\hline & & $\mathbf{b}$ & Std. Error & & & & $\begin{array}{l}\text { Lower } \\
\text { Bound }\end{array}$ & $\begin{array}{l}\text { Upper } \\
\text { Bound }\end{array}$ & Tolerance & VIF \\
\hline \multirow{4}{*}{1} & (Constant) & 0.452 & 0.108 & & 4.181 & 0.000 & 0.240 & 0.665 & & \\
\hline & Age & -0.009 & 0.001 & -0.329 & -8.183 & 0.000 & -0.011 & -0.007 & 0.931 & 1.074 \\
\hline & $E d u$ & 0.039 & 0.030 & 0.057 & 1.317 & 0.188 & -0.019 & 0.097 & 0.814 & 1.228 \\
\hline & $M H N I$ & 0.051 & 0.017 & 0.132 & 3.003 & 0.003 & 0.018 & 0.084 & 0.778 & 1.285 \\
\hline \multirow{8}{*}{2} & (Constant) & 0.467 & 0.116 & & 4.037 & 0.000 & 0.240 & 0.694 & & \\
\hline & Age & -0.005 & 0.001 & -0.177 & -4.696 & 0.000 & -0.007 & -0.003 & 0.787 & 1.270 \\
\hline & $E d u$ & 0.013 & 0.026 & 0.019 & 0.501 & 0.617 & -0.038 & 0.064 & 0.772 & 1.296 \\
\hline & MHNI & 0.012 & 0.015 & 0.031 & 0.782 & 0.434 & -0.018 & 0.042 & 0.690 & 1.450 \\
\hline & Feas & 0.280 & 0.043 & 0.241 & 6.451 & 0.000 & 0.194 & 0.365 & 0.796 & 1.256 \\
\hline & Stab & 0.286 & 0.037 & 0.299 & 7.791 & 0.000 & 0.214 & 0.358 & 0.755 & 1.324 \\
\hline & $\operatorname{Comf}$ & -0.063 & 0.019 & -0.126 & -3.371 & 0.001 & -0.100 & -0.026 & 0.792 & 1.263 \\
\hline & Work & -0.005 & 0.013 & -0.015 & -0.385 & 0.700 & -0.030 & 0.020 & 0.709 & 1.410 \\
\hline
\end{tabular}

Source: Author's computation. Note: ${ }^{a}$ Dependent Variable: Des.

The standardized beta values indicate that social stability $(\beta=0.299, \mathrm{t}(1023)=7.791)$ and feasibility $(\beta=0.241, t(1023)=6.451)$ have the most impact on the perceived desirability of entrepreneurship, followed by age $(\beta=-0.177, \mathrm{t}(1023)=-4.696)$ and comfort with acquiring customers $(\beta=-0.126$, $\mathrm{t}(782)=-3.371)$. The values of VIF (variance inflation factor) close to 1 indicate that there is no collinearity found between independent variables and, as such, in our regression model all predictor variables can independently predict the value of the dependent variable.

Neither "education", "working status" or "monthly household net-income" can predict the perceived desirability of entrepreneurship significantly. The variables were excluded as the $t$-test for equality of means generated a $\mathrm{t}$-value of 0.501 (Edu), 0.782 (MHNI), and -0.385 (Work) with a significance higher than the 0.05 threshold for significance. Therefore, hypotheses H5, H6 and H7 cannot be proved based on the existing data analyzed in the paper and have been rejected.

The summary of our research results is shown in Table 6.

Table 6. Research results.

\begin{tabular}{|c|c|c|c|c|}
\hline Hypothesis & Description & Variable & Coefficient & Findings \\
\hline H1: & $\begin{array}{l}\text { The feasibility of entrepreneurship is positively } \\
\text { related to the desirability of entrepreneurship }\end{array}$ & Feas & 0.280 & $\begin{array}{l}p<0.001 \\
\text { supported }\end{array}$ \\
\hline H2: & $\begin{array}{l}\text { The social stability is positively related to the } \\
\text { desirability of entrepreneurship }\end{array}$ & Stab & 0.286 & $\begin{array}{l}p<0.001 \\
\text { supported }\end{array}$ \\
\hline H3: & $\begin{array}{l}\text { The higher is the comfort with acquiring customers, } \\
\text { the stronger is the desirability of entrepreneurship }\end{array}$ & Comf & -0.063 & $\begin{array}{l}p<0.001 \\
\text { supported }\end{array}$ \\
\hline H4: & $\begin{array}{l}\text { The higher is the age, the lower is the desirability } \\
\text { of entrepreneurship }\end{array}$ & Age & -0.005 & $\begin{array}{l}p<0.001 \\
\text { supported }\end{array}$ \\
\hline H5: & $\begin{array}{l}\text { The higher is the level of education, the stronger is } \\
\text { the desirability of entrepreneurship }\end{array}$ & $E d u$ & 0.013 & $\begin{array}{l}p>0.05 \\
\text { rejected }\end{array}$ \\
\hline H6: & $\begin{array}{l}\text { The lower is the income, the higher is the desirability } \\
\text { of entrepreneurship }\end{array}$ & MHNI & 0.012 & $\begin{array}{l}p>0.05 \\
\text { rejected }\end{array}$ \\
\hline H7: & $\begin{array}{l}\text { There is a statistically significant effect of working } \\
\text { status on the desirability of entrepreneurship }\end{array}$ & Work & -0.005 & $\begin{array}{l}p>0.05 \\
\text { rejected }\end{array}$ \\
\hline
\end{tabular}

\section{Discussion}

Our research shows that stability against social pressure and feasibility of entrepreneurship to a high extent influence the perceived desirability of entrepreneurship. The higher the social stability and the higher the feasibility, the stronger the desirability of entrepreneurship. Stability against pressure from family and social environment has the most important impact on the perceived desirability of entrepreneurship. In addition, competencies, skills, and resources support entrepreneurship, and have 
the second-strongest impact on the perceived desirability of entrepreneurship. This confirms the results of Fishbein and Ajzen (2010) who pointed out that the best way to predict the entrepreneurial intentions of individuals is to measure their entrepreneurship possibilities [45]. Our results contradict Boukamcha's (2015) finding that there is no effect of the perceived feasibility of entrepreneurship on the trainees' desirability toward new venture creation [42]. However, our findings are in line with Fitzsimmons and Douglas's (2011) finding that highlights the importance of perceived feasibility in the desirability prediction [37]. In addition, our results confirm Shapero and Sokol's (1982) [17] and Krueger et al.'s (2000) [15] findings that highlight the positive influence of entrepreneurial self-efficacy and perceived feasibility on the individual's desirability toward new venture creation. Indeed, individuals who are confident of their skills and abilities to launch their own businesses tend to be highly motivated to start a new venture [98]. Mueller and Thomas (2001) came to a similar conclusion [102]. They found that the combination of personality traits and social environment has a very strong impact on a person's entrepreneurial attitude and intentions. Altinay and Altinay (2006) looked at this topic more closely and pointed out that this is mainly due to the exchange of knowledge within the social environment, as well as observations that improve entrepreneurial skills [103]. This is, for example, the result of an existing business model within the family. Additionally, it is easier to receive the required capital if family members are entrepreneurs, which influences the desirability of entrepreneurship [101,104]. Moreover, improvements in abilities and skills promote self-confidence, which helps people accept initial entrepreneurial challenges [99].

Our research also indicates that "comfort with acquiring customers" and "age" significantly influence the desirability of entrepreneurship. The higher the discomfort with identifying and retaining customers and the higher the age, the lower the desirability of entrepreneurship. Mamabolo et al. (2017) pointed out the necessity of acquiring knowledge and skills in domains such as marketing and customer relationship management to support entrepreneurial behavior [74]. Nehete et al. (2011) also argued about the significance of mastering marketing skills when embracing the entrepreneurship career decision [80]. Moreover, the desirability of entrepreneurship and self-employment decreases with age. In addition, age majorly influences the level of comfort with acquiring customers. The older the individuals get, the less they feel comfortable about searching and acquiring customers on a self-employed basis. Schoon and Duckworth (2012) found that older people believe their entrepreneurial opportunities and skills are more limited compared to younger people, which has a negative impact on self-confidence and risk preference [105]. Our results also confirm Minola et al.'s (2016) findings that show the significant negative influence of age on desirability beliefs [106].

Recent research has shown that education that is mainly focused on learning entrepreneurial skills has a positive impact on entrepreneurial intentions [25]. Other studies also concluded a positive relationship between education and the probability of entrepreneurship [89]. Diaz-Garcia et al. (2015) pointed out that this is due to a higher level of self-efficacy and the positive attitude that people show after entrepreneurial education programs [100]. Our research contradicts these findings and indicates that the level of education does not influence significantly the perceived desirability of entrepreneurship. However, our results are in line with Praag and Ophem's (1995) findings which reveal that in developing countries it seems that education has no influence on the entrepreneurial decision [90]. Hence, this would be interesting for future investigation. Education should not only include development of economic skills, but also should focus on business reality. This means on how to maintain the business by connecting to others and expanding the customer base.

Some recent studies point out that income level and working status influence entrepreneurial attitude and intentions [24,64]. However, our research shows that the monthly income level and the working status seem to be not significant predictors of the perceived desirability of entrepreneurship. As such, with our existing data, we cannot prove that working status and income influence the desirability of entrepreneurship and, further, entrepreneurial intentions in Romania. These hypotheses would be interesting for future research. 
The influence of self-employment on the desirability of entrepreneurship has been studied in recent years with different approaches and from different perspectives. Dewberry and Duncan (2018) [6], Bo (2017) [47], and Saeed et al. (2015) [53] carried out studies that focus on different skills and personality traits that are important for entrepreneurs. In summary, one can say that their results agree with our findings, which suggest that social stability, feasibility, age, and comfort with acquiring customers have the most impact on the desirability of starting one's own business in Romania. Despite this result, one should not disregard Krueger et al.'s (2000) finding that, besides personal potential, a positive attitude is necessary to transform desire into intention and further into behavior and action [15]. Future research can analyze whether this also applies to Romania.

\section{Conclusions}

The paper provides evidence on the factors that determine the perceived desirability of entrepreneurship and the willingness to start one's own business. The results of our multiple linear regression show a positive relationship with "social stability", "feasibility", and "desirability of entrepreneurship" and a negative correlation with "age" and "comfort with acquiring customers". In addition, we demonstrate that social stability and feasibility have the most impact on the perceived desirability of entrepreneurship. Moreover, we contribute to the literature through expanding existing knowledge on the determinants of desirability of entrepreneurship using the factor "comfort with acquiring customers". Our research results suggest that a good understanding of individuals' social environment and their need for skills and capabilities may lead to greater entrepreneurial efficacy, which is fundamental to sustaining economic growth.

Four of our hypotheses were proven. Feasibility of entrepreneurship and social environment have a strong positive influence on the perceived desirability of entrepreneurship. We also confirmed our hypothesis that the desirability of entrepreneurship decreases with increasing age, even if age by itself does not have too strong an effect on the perceived desirability of entrepreneurship. The same also applies to our third proven hypothesis, which states that the greater is the ease of acquiring customers, the stronger is the desirability of entrepreneurship and hence the desire to become an entrepreneur. Here, too, a positive influence was proven, but this one is not as strong as the other three influencing factors (feasibility of entrepreneurship, social stability, and age).

Since our results show that the two factors of feasibility of entrepreneurship and social environment have a strong positive influence on the desirability of entrepreneurship, the weighting of these two components should be considered to effectively promote entrepreneurship in Romania. In addition, it should be carefully considered in formulating the managerial implications. Education has a primary influence, especially when the acquired knowledge and the developed skills relate directly to the practical implementation of an independent activity. Most academic lectures, training courses, and education programs are focused on promoting expertise that can then be used within a company. If individuals want to set up their own business with the knowledge they learn here, then they will usually lack the necessary know-how, which can basically be gained by attending additional courses that are focused on entrepreneurship. However, since these courses only cover entrepreneurship in general and therefore cannot directly impart knowledge to course participants about which opportunities exist for successfully setting up their own business in a particular field, the participants are for the most part left to their own devices. This knowledge gap could be closed by teaching entrepreneurship not only as a separate field, but as a standard subfield together with the main expertise. An educational program that, for example, teaches students the specialist knowledge that is required for a successful career in marketing should then also show course participants how they can use this knowledge to set up their own business as a marketing consultant, for example. The program should cover, for example, the average hourly rate, customary costs in the industry, networks for acquiring customers, or studies of general market demand.

Another managerial implication that makes prospective entrepreneurs believe that entrepreneurship and self-employment are a more feasible option is the opportunity to exchange 
practical experiences with entrepreneurs. This could be combined with educational programs, thereby expanding the social environment of course participants to include entrepreneurs.

Our research has certain limits related to the nature and type of factors that determine the perceived desirability of entrepreneurship. The limited number of factors is given by the nature and structure of the research tool used, a global structured survey developed by Amway, which collects specific data on certain entrepreneurship-related issues. Therefore, our research did not include contextual factors or country specific factors regarding the socio-economic environment in Romania and this needs further attention in future research. Other studies considered the effect of other contextual factors $[9,10]$. Unlike these studies, our research focused on the direct influence of the individual-level and social-environmental factors on the desirability of entrepreneurship, without considering institutional or country-level factors, which in turn affect the perceived desirability of entrepreneurship.

In addition, based on the data for Romania that were available to us, we were unfortunately unable to prove whether the correlations of higher level of education to stronger desirability of entrepreneurship or lower income to higher desirability of entrepreneurship are true. Moreover, we were unable to prove whether working status significantly affects the perceived desirability of entrepreneurship. To analyze these hypotheses in a meaningful way, more participants in Romania should be interviewed in future studies.

Another research limit results from our initial hypothesis that the feasibility of entrepreneurship is positively related to the desirability of entrepreneurship, which is quite generally formulated. For future research papers, one could divide the term feasibility into sub-categories to determine which factors interviewees believe are decisive for developing a conviction that they can create a successful company.

Another limitation is represented by our measures of variables, which were assessed by means of a single item. However, previous studies have shown that single-item measures of well-defined constructs are reliable in individual or country level investigations $[107,108]$. In future research, we also intend to use the structural equation modelling to study the influence of existing studied factors and other country specific factors on the desirability of entrepreneurship, considering the interdependencies between these.

Author Contributions: All authors conceived and developed the research idea. The individual contributions of authors were as follows: Conceptualization, C.P., M.C.P. and M.D.; Methodology, C.P.; Validation, C.P., M.C.P. and M.D.; Formal Analysis, C.P.; Investigation, C.P., M.C.P. and M.D.; Writing-Original Draft Preparation, C.P. and M.P.; Writing-Review \& Editing, C.P., M.C.P. and M.D.; Project Administration, C.P. All three authors wrote the manuscript, thoroughly read it, and approved the final version.

Funding: This research received no external funding.

Acknowledgments: Authors are thankful to the editor and reviewers for their thoughtful comments, constructive criticisms and valuable suggestions, which made possible improvement and finalization of this article.

Conflicts of Interest: The authors declare no conflict of interest.

\section{References}

1. Hoogendoorn, B.; Van der Zwan, P.; Thurik, R. Sustainable entrepreneurship: The role of perceived barriers and risk. J. Bus. Ethics 2016, 151, 1-22. [CrossRef]

2. Crecente-Romero, F.; Gimenez-Baldazo, M.; Rivera-Galicia, L.F. Can entrepreneurship channel over qualification in young university graduates in the European Union? J. Bus. Res. 2018, 89, 223-228. [CrossRef]

3. Global Entrepreneurship Research Association (GERA). Global Entrepreneurship Monitor 2017/2018; GERA: London, UK, 2018.

4. Matos, S.; Hall, J. Integrating sustainable development in the Supply Chain Management: The case of life cycle assessment in oil and gas and agricultural technology. J. Oper. Manag. 2007, 25, 1083-1102. [CrossRef]

5. Schlaegel, C.; Koenig, M. Determinants of entrepreneurial intent: A meta-analytic test and integration of competing models. Entrep. Theory Pract. 2014, 38, 291-332. [CrossRef] 
6. Dewberry, C.; Duncan, J.R. An application of the theory of planned behavior to student retention. J. Vocat. Behav. 2018, 107, 100-110. [CrossRef]

7. Dohse, D.; Walter, S.G. Knowledge context and entrepreneurial intentions among students. Small Bus. Econ. 2012, 39, 877-895. [CrossRef]

8. Sánchez, J.C. University training for entrepreneurial competencies: Its impact on intention of venture creation. Int. Entrep. Manag. J. 2011, 7, 239-254. [CrossRef]

9. Dumitru, I.; Dumitru, I. Entrepreneurship determinants in Central and Eastern Europe. The case of Romania. Econ. Comput. Econ. Cybern. Stud. Res. 2017, 51, 187-203.

10. Falck, O.; Woessmann, L. School competition and student's entrepreneurial intentions: International evidence using historical Catholic roots of private schooling. Small Bus. Econ. 2013, 40, 459-478. [CrossRef]

11. Lee, S.M.; Chang, D.; Lim, S.B. Impact of entrepreneurship Education: A Comparative Study of the U. S. and Korea. Int. Entrep. Manag. J. 2005, 1, 27-43. [CrossRef]

12. Peng, Z.; Lu, L.; Kang, H. Entrepreneurial intentions and its influencing factors: A survey of the university students in Xi'an China. Creat. Educ. 2012, 3, 95-100. [CrossRef]

13. Riquelme, H.E.; Al Lanqawi, A. The desire that propels entrepreneurial intentions. J. Entrep. Manag. Innov. 2016, 12, 123-150. [CrossRef]

14. Krueger, N., Jr. The impact of prior entrepreneurial exposure on perceptions of new venture feasibility. Entrep. Theory Pract. 1993, 18, 5-21. [CrossRef]

15. Krueger, N.F.; Carsrud, A.; Reilly, M.D. Competing models of entrepreneurial intentions. J. Bus. Ventur. 2000, 15, 411-432. [CrossRef]

16. Ajzen, I. The theory of planned behavior. Organ. Behav. Hum. Decis. Process 1991, 50, 179-211. [CrossRef]

17. Shapero, A.; Sokol, L. The social dimensions of entrepreneurship. In Encyclopedia of Entrepreneurship; University of Illinois: Urbana, IL, USA, 1982; pp. 72-90.

18. Popescu, C.C.; Bostan, I.; Robu, I.B.; Maxim, A.; Diaconu (Maxim), L. An analysis of the determinants of entrepreneurial intentions among students: A Romanian case study. Sustainability 2016, 8, 771. [CrossRef]

19. Nitu-Antonie, R.D.; Feder, E.S. The role of economic academic education on entrepreneurial behavior. Amfiteatru Econ. 2015, 17, 261-276.

20. Anton, S.G.; Bostan, I. The role of access to finance in explaining cross-national variation in entrepreneurial activity: A panel data approach. Sustainability 2017, 9, 1947. [CrossRef]

21. Brancu, L.; Gudmundsdottir, S.; Gligor, D.; Munteanu, V. Is culture a moderator of entrepreneurship motivation? A comparative study of Romania and Iceland. Amfiteatru Econ. 2015, 17, 133-147.

22. Hall, J.; Daneke, G.A.; Lenox, M.J. Sustainable development and entrepreneurship: Past contributions and future directions. J. Bus. Ventur. 2010, 25, 439-448. [CrossRef]

23. Cohen, B.; Winn, M. Market imperfections, opportunity and sustainable entrepreneurship. J. Bus. Ventur. 2007, 22, 29-49. [CrossRef]

24. Kaiser, U.; Moller, N.M. Is self-employment really a bad experience? The effects of previous self-employment on subsequent wage-employment wages. J. Bus. Ventur. 2011, 26, 572-588. [CrossRef]

25. Bae, T.J.; Qian, S.; Miao, C.; Fiet, J.O. The relationship between entrepreneurship education and entrepreneurial intentions: A meta-analytic review. Entrep. Theory Pract. 2014, 38, 217-254. [CrossRef]

26. Wu, S.; Wu, L. The impact of higher education on entrepreneurial intentions of university students in China. J. Small Bus. Entrep. Dev. 2008, 15, 752-774. [CrossRef]

27. Thompson, E.R. Individual entrepreneurial intent: Construct clarification and development of an internationally reliable metric. Entrep. Theory Pract. 2009, 33, 669-694. [CrossRef]

28. Bandura, A. Self-efficacy: Toward a unifying theory of behavioral change. Psychol. Rev. 1977, 2, 191-215. [CrossRef]

29. Liñán, F.; Chen, Y.-W. Development and cross-cultural application of a specific instrument to measure entrepreneurial intentions. Entrep. Theory Pract. 2009, 33, 593-617. [CrossRef]

30. Fellnhofer, K. Narratives boost entrepreneurial attitudes: Making an entrepreneurial career attractive? Eur. J. Educ. 2018, 53, 218-237. [CrossRef] [PubMed]

31. Zampetakis, L.A.; Kafetsios, K.; Moustakis, V. Using emotional persuasion for changing attitudes towards entrepreneurship: An interpersonal perspective. J. Bus. Ventur. Insights 2017, 7, 50-54. [CrossRef]

32. Gollwitzer, P. The volitional benefits of planning. In The Psychology of Action: Linking Cognition and Motivation to Behavior; Gollwitzer, P., Bargh, J., Eds.; Guilford: New York, NY, USA, 1996; pp. 287-312. 
33. Peterman, N.E.; Kennedy, J. Enterprise education: Influencing students' perceptions of entrepreneurship. Entrep. Theory Pract. 2003, 28, 129-144. [CrossRef]

34. Krueger, N.F.; Brazeal, D.V. Entrepreneurial potential and potential entrepreneurs. Entrep. Theory Pract. 1994, 18, 91-104. [CrossRef]

35. Jakopec, A.; Krecar, I.M.; Susanj, Z. Predictors of entrepreneurial intentions of students of economics. Studia Psychol. 2013, 55, 289-297. [CrossRef]

36. Vuorio, A.M.; Puumalainen, K.; Fellnhofer, K. Drivers of entrepreneurial intentions in sustainable entrepreneurship. Int. J. Entrep. Behav. Res. 2018, 24, 359-381. [CrossRef]

37. Fitzsimmons, J.R.; Douglas, E.J. Interaction between feasibility and desirability in the formation of entrepreneurial intentions. J. Bus. Ventur. 2011, 26, 431-440. [CrossRef]

38. Vazquez, J.L.; Naghui, A.; Gutierrez, P.; Lanero, A.; Garcia, M.P. Entrepreneurial potential in the university: Intentions and attitudes towards new venture creation. Bull. UASVM Hortic. 2009, 66, 507-512.

39. Barton, M.; Schaefer, R.; Canavati, S. To be or not to be a social entrepreneur: Motivational drivers amongst American business students. Entrep. Bus. Econ. Rev. 2018, 6, 9-35. [CrossRef]

40. Bagozzi, R. The self-regulation of attitudes, intentions and behavior. Soc. Psychol. Q. 1992, 55, 178-204. [CrossRef]

41. Segal, G.; Borgia, D.; Schoenfeld, J. The motivation to become an entrepreneur. Int. J. Entrep. Behav. Res. 2005, 11, 42-57. [CrossRef]

42. Boukamcha, F. Impact of training on entrepreneurial intention: An interactive cognitive perspective. Eur. Bus. Rev. 2015, 27, 593-616. [CrossRef]

43. Hockerts, K. The social entrepreneurial antecedents scale (SEAS): A validation study. Soc. Entrep. J. 2015, 11, 260-280. [CrossRef]

44. Urban, B.; Kujinga, L. The institutional environment and social entrepreneurship intentions. Int. J. Entrep. Behav. Res. 2017, 23, 638-655. [CrossRef]

45. Fishbein, M.; Ajzen, I. Predicting and Changing Behavior: The Reasoned Action Approach; Psychology Press (Taylor \& Francis): New York, NY, USA, 2010; pp. 87-236.

46. Ingram, K.L.; Cope, J.G.; Harju, B.L.; Wuensch, K.L. Applying to graduate school: A test of the theory of planned behavior. J. Soc. Behav. Personal. 2000, 15, 215-225.

47. Bo, Z. Research on cultivation scheme based on TPB of entrepreneurial talents in Chinese local application-oriented universities. Eurasia J. Math. Sci. Technol. Educ. 2017, 13, 5629-5636. [CrossRef]

48. Ding, W.; Choi, E. Divergent paths to commercial science: A comparison of scientists founding and advising activities. Res. Policy 2011, 40, 69-80. [CrossRef]

49. Erikson, T. Towards a taxonomy of entrepreneurial learning experiences among potential entrepreneurs. J. Small Bus. Entrep. Dev. 2003, 10, 106-112. [CrossRef]

50. Carr, J.C.; Sequeira, J.M. Prior family business exposure as intergenerational influence and entrepreneurial intent: A theory of planned behavior approach. J. Bus. Res. 2006, 60, 1090-1098. [CrossRef]

51. Goethner, M.; Silbereisen, R.K.; Obschkonka, M.; Cantner, U. Scientists transition to academic entrepreneurship: Economic and psychological determinants. J. Econ. Psychol. 2012, 33, 628-641. [CrossRef]

52. Mosey, S.; Wright, M. From the human capital to social capital: A longitudinal study of technology-based academic entrepreneurs. Entrep. Theory Pract. 2007, 31, 909-935. [CrossRef]

53. Saeed, S.; Yani-de-Soriano, M.; Yousafoi, S.; Muffatto, M. The role of perceived university support in the formation of students' entrepreneurial intention. J. Small Bus. Manag. 2015, 53, 1127-1145. [CrossRef]

54. Fayolle, A.; Linan, F. The future of research on entrepreneurial intentions. J. Bus. Res. 2014, 67, $663-666$. [CrossRef]

55. Miranda, F.J.; Chamorro-Mera, A.; Rubio, S. Academic entrepreneurship in Spanish universities: An analysis of the determinants of entrepreneurial intention. Eur. Res. Manag. Bus. Econ. 2017, 23, 113-122. [CrossRef]

56. Nicolae, M.; Ion, I.; Nicolae, E. Regional differences in entrepreneurial perceptions and implications for the Romanian competitiveness policy. Manag. Mark. Chall. Knowl. Soc. 2016, 11, 394-409. [CrossRef]

57. Fini, R.; Lacetera, N.; Shane, S. Inside or outside the IP system? Business creation in academia. Econ. J. 2010, 39, 1060-1069. [CrossRef]

58. Moog, S.; Spicer, A.; Bohm, S. The politics of multi- stakeholder initiatives: The crisis of the forest stewardship council. J. Bus. Ethics 2015, 128, 469-493. [CrossRef] 
59. Douglas, E.; Sheperd, D.A. Entrepreneurship as a utility maximizing response. J. Bus. Ventur. 2000, 15, 231-251. [CrossRef]

60. Hikkerova, L.; Ilouga, S.N.; Sahut, J.M. The entrepreneurship process and the model of volition. J. Bus. Res. 2016, 6, 1868-1873. [CrossRef]

61. Gollwitzer, P.M.; Heckhausen, H. Thought contents and cognitive functioning in motivational versus volitional states of mind. Motiv. Emot. 1987, 11, 101-120.

62. Broonen, J.P. Des intentions aux actes: La volition en conseil en orientation. L'Orientat. Scollaire Prof. 2010, 39, 137-171. [CrossRef]

63. Forstmeier, S.; Ruddel, H. Measuring volitional competences: Psychometric properties of a short form of the volitional components questionnaire (VCQ) in a clinical sample. Open Psychol. J. 2008, 11, 66-77. [CrossRef]

64. Failla, V.; Melillo, F.; Reichstein, T. Entrepreneurship and employment stability-Job matching, labor market value, and personal commitment. J. Bus. Ventur. 2017, 32, 162-177. [CrossRef]

65. Bruce, D.; Schuetze, N. The labor market consequences of experience in self-employment. Labour Econ. 2004, 11, 575-598. [CrossRef]

66. DeTienne, D.R.; Cardon, M.S. The impact of new venture design an entrepreneurial exit. Front. Entrep. Res. 2008, 28, 1-14.

67. Zampetakis, L.A.; Bakatsaki, M.; Litos, C.; Kafetsios, K.G.; Moustakis, V. Gender-based differential item functioning in the application of the theory of the planned behavior for the study of entrepreneurial intentions. Front. Psychol. 2017, 8, 451. [CrossRef] [PubMed]

68. Van Kleef, G.A. How emotions regulate social life: The emotions as social information (EASI) model. Curr. Dir. Psychol. Sci. 2009, 18, 184-188. [CrossRef]

69. Păunescu, C.; Roșu, R. Propensity for hybrid entrepreneurship among females. Entrep. Innov. 2017, 34, 38-49. [CrossRef]

70. Mitchell, J.R.; Shepperd, D.A. Afraid of opportunity: The effects of fear of failure an entrepreneurial decisions. Front. Entrep. Res. 2011, 31, 1-16.

71. Farrukh, M.; Ying, C.; Mansori, S. Intrapreneurial behavior: An empirical investigation of personality traits. Manag. Mark. Chall. Knowl. Soc. 2016, 11, 597-609. [CrossRef]

72. Cacciotti, G.; Hayton, J.C.; Mitchell, J.R.; Giazitzoglu, A. A reconceptualization of fear of failure in entrepreneurship. J. Bus. Ventur. 2016, 31, 302-325. [CrossRef]

73. Cantaragiu, R.; Păunescu, C.; Hadad, S. The social impact of university entrepreneurship in Romania: Is the institutional discourse replicated or adapted? Manag. Mark. Chall. Knowl. Soc. 2014, 9, 403-422.

74. Mamabolo, M.A.; Kerrin, M.; Kele, T. Entrepreneurship management skills requirements in an emerging economy: A South African outlook. South. Afr. J. Entrep. Small Bus. Manag. 2017, 9, 1-10. [CrossRef]

75. Păunescu, C.; Pascu, A.I.; Pop, O. Social enterprise: How does this way of doing business differ from other forms of enterprise? Qual. Access Success 2016, 17, 108-110.

76. Obschonka, M.; Rodermund-Schimtt, E.; Silbereisen, R.K.; Gosling, S.D.; Potter, J. Towards a geography of entrepreneurial personality. Front. Entrep. Res. 2012, 32, 1-12.

77. Hayton, J.C.; McEvoy, G.M. Developing and assessing professional and managerial competence. Hum. Resour. Manag. 2006, 45, 291-293. [CrossRef]

78. Morales, C.; Marquina, P.S. Entrepreneurial skills, significant differences between Serbian and German entrepreneurs. Bus. Econ. Res. J. 2013, 6, 129-141. [CrossRef]

79. Mitchelmore, S.; Rowley, J. Entrepreneurial competencies of women entrepreneurs pursuing business growth. J. Small Bus. Entrep. Dev. 2013, 20, 125-142. [CrossRef]

80. Nehete, R.; Narkhede, B.E.; Mahajan, S.K. Investigation of entrepreneurial skills for better performance of manufacturing SMEs. Int. J. Eng. Sci. Technol. 2011, 3, 5515-5525.

81. Boyatzis, R.E.; Kolb, D.A. From learning styles to learning skills: The executive skills profile. J. Manag. Psychol. 1995, 10, 3-17. [CrossRef]

82. Chen, C.C.; Greene, P.G.; Crick, A. Does entrepreneurial self-efficacy distinguish entrepreneurs from managers? J. Bus. Ventur. 1998, 13, 295-316. [CrossRef]

83. Groves, K.; Păunescu, C. Examining the antecedents and outcomes of Romanian entrepreneurial orientation. Manag. Mark. 2008, 3, 3-18.

84. Dahlstrom, T.; Talmage, C.A. Entrepreneurial skills for sustainable small business: An exploratory of SCORE, with Comparison. Community Dev. 2018, 49, 450-468. [CrossRef] 
85. Wiek, A.; Withycombe, L.; Redman, C.L. Key competencies in sustainability: A reference framework for academic program development. Sustain. Sci. 2011, 6, 203-218. [CrossRef]

86. Hesselbarth, C.; Schaltegger, S. Educating change agents for sustainability-Learnings from the first sustainability management master of business administration. J. Clean. Prod. 2014, 62, 24-36. [CrossRef]

87. Lans, T.; Blok, V.; Wesselnik, R. Learning apart and together: Towards an integrated competence framework for sustainable entrepreneurship in higher education. J. Clean. Prod. 2014, 62, 37-47. [CrossRef]

88. Ploum, L.; Blok, V.; Lans, T.; Omta, O. Toward a validated competence framework for sustainable entrepreneurship. Organ. Environ. 2017, 31, 113-132. [CrossRef]

89. Moore, C.; Mueller, R. The transition from paid to self-employment in Canada: The importance of push factors. Appl. Econ. 2002, 34, 791-801. [CrossRef]

90. Praag, M.; Ophem, H. Determinants of willingness and opportunity to start as entrepreneur. Kyklos 1995, 1995. 48, 513-540. [CrossRef]

91. Sluis, J.; Praag, M.; Vijverberg, W. Entrepreneurship selection and performance: A meta-analysis of the impact of education in developing economies. World Bank Econ. Rev. 2005, 19, 225-261. [CrossRef]

92. Stefanović, S.; Stošić, D. Age and education as determinants of entrepreneurship. Econ. Organ. 2012, 9, 327-339.

93. Deli, F. Opportunity and necessity entrepreneurship: Local unemployment and the small firm effect. J. Manag. Policy Pract. 2011, 12, 38-57.

94. Bates, T. Self-employment entry across industry groups. J. Bus. Ventur. 1995, 10, 143-156. [CrossRef]

95. Parker, S.C. The Economics of Entrepreneurship: What We Know and What We Don't? Publishers Inc.: Hanover, Germany, 2005; pp. 7-40. ISBN 1-933019-08-5.

96. Păunescu, C.; Blid, O. Seniorpreneur as a career option for smart active ageing. A study on Romania. In Proceedings of the 11th International Conference on Business Excellence, Strategy, Complexity and Energy in Changing Times, Bucharest, Romania, 30-31 March 2017; Volume 11, pp. 826-9652. [CrossRef]

97. Davaria, A.; Farokhmaneshb, T. Impact of entrepreneurship policies on opportunity to startup. Manag. Sci. Lett. 2017, 7, 431-438. [CrossRef]

98. Lee, L.; DerFoo, M.; Wong, P.K.; Leung, A. Entrepreneurial intentions: The influence of organizational and individual factors. J. Bus. Ventur. 2011, 26, 124-136. [CrossRef]

99. Mau, W.C. Factors that influence persistence in science and engineering career aspirations. Career Dev. $Q$. 2003, 51, 234-243. [CrossRef]

100. Diaz-Garcia, C.; Saez-Martinez, F.; Jimenez-Moreno, J. Assessing the impact of the "Entrepreneurs Education Programme" on participants' entrepreneurial intentions. Univ. Knowl. Soc. J. 2015, 12, 17-31. [CrossRef]

101. Dunn, T.; Holtz-Eakin, D. Financial capital, human capital, and the transition to self-employment: Evidence from intergenerational links. J. Labor Econ. 2000, 18, 282-305. [CrossRef]

102. Mueller, S.L.; Thomas, A.S. Culture and entrepreneurial potential. J. Bus. Ventur. 2001, 16, 51-75. [CrossRef]

103. Altinay, L.; Altinay, E. Determinants of ethnic minority entrepreneurial growth in the catering sector. Serv. Ind. J. 2006, 26, 203-221. [CrossRef]

104. Aldrich, H.E.; Linda, R.A.; Nancy, L. Passing on privilege: Resources provided by self-employed parents to their self-employed children. Res. Soc. Stratif. Mobil. 1998, 16, 291-317.

105. Schoon, I.; Duckworth, K. Who becomes an entrepreneur? Early life experiences as predictors of entrepreneurship. Dev. Psychol. 2012, 48, 1719-1726. [CrossRef] [PubMed]

106. Minola, T.; Criaco, G.; Obschonka, M. Age, culture, and self-employment motivation. Small Bus. Econ. 2016, 46, 187-213. [CrossRef]

107. Lucas, R.E.; Donnellan, M.B. If the person-situation debate is really over, why does it still generate so much negative affect? J. Res. Personal. 2009, 43, 146-149. [CrossRef]

108. Robins, R.W.; Hendin, H.M.; Trzesniewski, K.H. Measuring global self-esteem: Construct validation of a single-tem measure and the Rosenberg self-esteem scale. Personal. Soc. Psychol. Bull. 2001, 27, 151-161. [CrossRef]

(C) 2018 by the authors. Licensee MDPI, Basel, Switzerland. This article is an open access article distributed under the terms and conditions of the Creative Commons Attribution (CC BY) license (http:// creativecommons.org/licenses/by/4.0/). 